\title{
Optimisation of ultrasound-assisted extraction of pectinase enzyme from Guava (Psidium guajava) peel: enzyme recovery, specific activity, temperature and storage stability
}

\begin{abstract}
This study aimed to investigate the effects of the ultrasound-assisted extraction conditions on the yield, specific activity, temperature, and storage stability of the pectinase enzyme from guava peel. The ultrasound variables studied were sonication time (10-30 min), ultrasound temperature $\left(30-50^{\circ} \mathrm{C}\right), \mathrm{pH}(2.0-8.0)$, and solvent-to-sample ratio $(2: 1 \mathrm{~mL} / \mathrm{g}$ to $6: 1 \mathrm{~mL} / \mathrm{g})$. The main goal was to optimize the ultrasound-assisted extraction conditions to maximize the recovery of pectinase from guava peel with the most desirable enzyme-specific activity and stability. Under the optimum conditions, a high yield (96.2\%), good specific activity (18.2 $\mathrm{U} / \mathrm{mg}$ ), temperature stability $(88.3 \%)$, and storage stability $(90.3 \%)$ of the extracted enzyme were achieved. The optimal conditions were 20 min sonication time, $40^{\circ} \mathrm{C}$ temperature, at $\mathrm{pH}$ 5.0 , using a $4: 1 \mathrm{~mL} / \mathrm{g}$ solvent-to-sample ratio. The study demonstrated that optimization of ultrasound-assisted process conditions for the enzyme extraction could improve the enzymatic characteristics and yield of the enzyme.
\end{abstract}

Keyword: Enzymatic properties; Extraction; Guava peel; Pectinase; Ultrasound-assisted process; Yield 